\title{
Notes on Contributors / Notices biographiques
}

THOMAS ABRAMS is a postdoctoral fellow at the Department of Social Justice Education at the Ontario Institute for Studies in Education (University of Toronto). His interests include disability studies, phenomenology, and sociological theory. His recent publications include "Cartesian Dualism and Disabled Phenomenology," Scandinavian Journal of Disability Research (2015), and "Flawed by Dasein? Phenomenology, Ethnomethodology, and the Personal Experience of Physiotherapy," Human Studies (2014).

NORMAND BAILLARGEON est titulaire d'un doctorat en éducation et d'un doctorat en philosophie. Il enseigne en éducation à l'Université du Québec à Montréal depuis 1989, et depuis plus de 20 ans il intervient régulièrement dans divers médias au Québec. Il est l'auteur de nombreux articles, livres et anthologies, ainsi que de traductions. Parmi ses publications récentes figurent L'Arche de Socrate. Petit bestiaire philosophique (La Grande Bruxelles, 2012), les Chroniques des années molles (Leméac, 2014) et la direction de Mutations de l'univers médiatique: médias traditionnels et nouveaux (M Éditeur, 2014) et de L'assaut contre les retraites (M Éditeur, 2015).

DON BEITH works on questions of development, temporality, and embodiment in phenomenology. His paper on the concept of generative passivity in the works of Merleau-Ponty was recently published in Chiasmi International. He is a Lecturer in the Department of Philosophy at the University of British Columbia, where he teaches existentialism, phenomenology, and Kant.

MARC DE KESEL is professor of philosophy at Saint Paul University, Ottawa. He specializes in continental philosophy, Lacanian theory, Shoah studies, and theories of religion. He is the author of Eros \& Ethics: Reading Jacques Lacan, Séminaire VII (SUNY Press, 2009), and, in Dutch, Goden breken. Essays over monotheïsme (Amsterdam: Boom, 2010), Auschwitz mon amour (Boom, 2012), and Žižek (Amsterdam, 2012).

OLIVIER DUCHARME est chercheur postdoctoral au Laboratoire de philosophie continentale de l'Université Laval, où il poursuit des études sur la théorie queer et le cinéma. Il est l'auteur des livres Michel Henry et le problème de la communauté. Pour une communauté d'habitus 
(L'Harmattan, 2013) et, en collaboration avec Pierre-Alexandre Fradet, de Une vie sans bon sens. Regard philosophique sur Pierre Perrault (Nota bene, 2015).

TILL DÜPPE is Assistant Professor at the Université du Québec à Montréal. His research interest is the historical epistemology of economics, inspired by phenomenological philosophy. $\mathrm{He}$ is the author of the books The Making of the Economy: A Phenomenology of Economic Science (Lexington) and, together with E. Roy Weintraub, Finding Equilibrium: Arrow, Debreu, Mckenzie, and the Problem of Scientific Credit (Princeton).

CARLO GENTILI est professeur en esthétique au Département de philosophie de l'Université de Bologne, où il travaille sur la philosophie de Nietzsche et sur l'herméneutique. Il siège au comité scientifique des Nietzsche-Studien. Parmi ses publications récentes figurent «Nietzsche y el Cristianismo »(dans le volume Guía Comares de Nietzsche, Grenade, 2014), «Der Begriff Europas. Friedrich Nietzsche und Karl Löwith im Vergleich» (dans le volume «Einige werden posthum geboren». Nietzsches Wirkungen, de Gruyter, 2012), Nietzsches Kulturkritik zwischen Philologie und Philosophie (Schwabe, 2010) et, avec G. Garelli, Il tragico (Il Mulino, 2010).

REBECCA GLENN SCOTT is a PhD candidate in philosophy at Loyola University, Chicago. Her research interests include phenomenology, ethics, and the philosophy of education. She is currently finishing her dissertation on the theme of teaching in the work of Emmanuel Levinas with a focus on the relationship between Levinas and Plato. She is also a board member of the American Association of Philosophy Teachers.

DENIZ GUVENC is a graduate student in the Department of Philosophy at the University of Ottawa. His research interests include German philosophy, aesthetics, and political philosophy.

KATHY KILOH is an instructor in the School of Graduate Studies and the Faculty of Liberal Arts and Sciences at OCAD University in Toronto. She is currently completing a book-length manuscript entitled The Power to be Weak: Aesthetic Self-relinquishment and the Ethical Relation in Adorno and Levinas.

CHRISTOPHER LAPIERRE, ancien élève de l'ENS de Lyon, est agrégé de philosophie et chercheur au Centre Georges Chevrier (UMR 7366) de l'Université de Bourgogne. Partant des thèmes de l'imagination, de l'affectivité et de la vie, ses recherches interrogent les marges de la rationalité. Il participe à ce titre aux séminaires de l'École française de Daseinsanalyse. Son travail aborde également des questions d'esthétique, notamment quant au statut de la parole poétique. S'inscrivant dans le prolongement d'une pratique poétique qui a donné lieu à un recueil en 
2010 (Phloème, 2005-2010), il interroge les relations du langage à l'imaginaire et à l'incarnation.

FRÉDÉRIC MERCURE-JOLETTE est professeur au Département de philosophie du Cégep Saint-Laurent (Montréal) et candidat au doctorat en science politique à l'Université de Montréal. Ses recherches portent sur l'histoire des idées politiques et l'histoire de l'urbanisme et des politiques urbaines. Il participe au blogue de la revue indisciplinée Trahir (https://trahir.wordpress.com/) et est membre du comité éditorial de Moult éditions (http://moulteditions.com/).

MARIE-ÈVE MORIN is associate professor of Philosophy at the University of Alberta (Edmonton). Her research interests include phenomenology, existentialism, and deconstruction. She is the author of Jean-Luc Nancy, an introduction to Nancy's work for Polity Press's "Key Contemporary Thinkers" series, as well as of articles on Heidegger, Sartre, Derrida, Nancy, and Sloterdijk. She is currently working on a comparative study of Nancy's and Merleau-Ponty's ontologies in light of the speculative realist challenge.

ANNA MUDDE is Assistant Professor of philosophy at Campion College at the University of Regina. She works in feminist epistemology and philosophy of science, metaphysics, and Beauvoirean philosophy, and on self-knowledge, subjectivity, and responsibility. Her current projects focus on the use of lived social categories to know and deal with human bodies, and the ways material objects, practices (technologies), and the metaphors they produce (e.g., the mirror and reflection) shape embodied practices of problem-solving and making-sense.

PETER ODABACHIAN a étudié au département de philosophie de l'Université de Montréal. Il enseigne la philosophie au Collège ÉdouardMontpetit depuis 2007. Ses recherches sur la mémoire se sont tenues jusqu'ici dans le sillage de l'héritage critique et romantique de notre modernité philosophique. 